\title{
Erratum to: Formation of Fine Clusters in High-Temperature Oxidation of Molten Aluminum
}

\author{
KEEHYUN KIM
}

DOI: $10.1007 / \mathrm{s} 11661-014-2350-\mathrm{x}$

(C) The Minerals, Metals \& Materials Society and ASM International 2014

Erratum to: METALLURGICAL AND MATERIALS

TRANSACTIONS A

DOI 10.1007/s11661-014-2270-9

FIRST page, Introduction, left column. The correct equation is as follows:

$$
\begin{gathered}
4 \mathrm{Al}_{(\mathrm{s})}+3 \mathrm{O}_{2(\mathrm{~g})}=2 \mathrm{Al}_{2} \mathrm{O}_{3(\mathrm{~s})} \\
{\left[\text { for } 298 \mathrm{~K}\left(25^{\circ} \mathrm{C}\right)<T<933 \mathrm{~K}\left(660^{\circ} \mathrm{C}\right)\right]} \\
\Delta G^{\circ}=-3,334,000-33.4 \log T+733.4 T \\
4 \mathrm{Al}_{(\mathrm{l})}+3 \mathrm{O}_{2(\mathrm{~g})}=2 \mathrm{Al}_{2} \mathrm{O}_{3(\mathrm{~s})} \\
{\left[\text { for } 933 \mathrm{~K}\left(660^{\circ} \mathrm{C}\right)<T<1800 \mathrm{~K}\left(1527^{\circ} \mathrm{C}\right)\right]} \\
\Delta G^{\circ}=-3,396,000-31.4 \log T+771.6 T
\end{gathered}
$$

KEEHYUN KIM, Research Fellow, is with The EPSRC Centre for Innovative Manufacturing in Liquid Metal Engineering, School of Metallurgy and Materials, University of Birmingham, Birmingham B15 2TT, U.K. Contact e-mail: k.kim.2@bham.ac.uk

The online version of the original article can be found under doi: 10.1007/s11661-014-2270-9.

Article published online May 14, 2014 